\title{
16
}

\section{Bureaucratic, Professional and Managerial Power in University Tenure Track Recruitment}

\section{Tea Vellamo, Jonna Kosonen, Taru Siekkinen, and Elias Pekkola}

\section{Introduction}

Finnish higher education policy has followed the global trend of providing more autonomy to universities, including independent personnel policies. In the 2010 higher education reform, the status of Finnish universities was changed from public bureaus to foundations and corporations under public law. Meanwhile, the status of university personnel was changed from civil servants to employees. Universities were granted independent status as employers, and they were empowered with their own

\footnotetext{
T. Vellamo $(\bowtie) \bullet$ E. Pekkola

Tampere University, Tampere, Finland

e-mail: tea.vellamo@tuni.fi

J. Kosonen

University of Eastern Finland, Kuopio, Finland

T. Siekkinen

University of Jyväskylä, Jyväskylä, Finland

(C) The Author(s) 2022 
human resource management (HRM) practices independent from state human resource policies (Kivistö et al., 2019; Siekkinen et al., 2016).

During the 1990s and 2000s, in most Finnish universities, personnel and financial decision-making were gradually transferred from collegial (tripartite) multimember bodies to rectors and deans. This resulted in the managerialisation, centralisation and professionalisation of decisionmaking in personnel affairs. Simultaneously, tenure track systems were introduced. Consequently, the role of internal academic bodies was weakened while that of institutional managers and external scientific evaluation was strengthened (e.g. Pekkola, 2014; Siekkinen, 2019). At the same time, with their new organisational form, universities were becoming more goal-oriented with unified strategies, more managerial central coordination and control, and building organisational identities related to these practices (Pietilä, 2015).

In this chapter, we are interested in tenure recruitment at a technical university. We analyse how tenure track recruitment in similar fields reveal differences between a technical foundation university and a multidisciplinary corporate university. For this, we compare the tenure track recruitment process of Tampere University of Technology (TUT) and the University of Tampere (UTA). TUT and UTA are an interesting pair to compare as they represent very different kinds of universities organisationally and discipline-wise. The two universities merged in 2019 and their different recruitment processes are now being formed anew. Since 2010 most recruitments have still been open vacancies; less than $10 \%$ of the recruitments at TUT were international tenure track recruitments, whereas at UTA the ratio was less than 5\% (statistic from 2010-2014, Välimaa et al., 2016). In UTA, tenure track recruitments were limited in number, but they were open in varied fields from education and medicine to game culture.

We specifically focus on the recruitment process and criteria, the different powers within the process and the way they are related to the organisational identity of the technical foundation university as compared to the multidisciplinary university. The analysis was conducted on the practices of the two universities prior to their merger, examining documents from 2011 to 2017. Concerning the recruitment process and criteria, we ask the following question: 
- How are bureaucratic, managerial and professional powers manifested in the tenure track recruitment processes?

It is interesting to analyse the tenure track recruitment process in similar fields, and therefore we chose our cases from Computer Science (TUT) and Information Technology (UTA). As the fields are similar, the way these different powers are present in the recruitment process may be related to the organisational form and organisational identity of the two universities. This hypothesis is supported by (currently scarce) empirical evidence on the differences between Finnish comprehensive universities and technical universities, which suggests that the management culture in technical universities is more managerial (Pekkola, 2011, 2014) and the identity of its staff members is more entrepreneurial (Vellamo et al., 2019). We would anticipate that these aspects are visible in the recruitment process as well. Our analysis may contribute to increasing transparency in recruitment processes by disclosing information on the agents, their power balance, their criteria and their evaluation and decisionmaking processes.

\section{Selection and Recruitment of Candidates: A Regulative Perspective}

All Finnish universities are regulated by the same legislation concerning their personnel, primarily defined by labour law, which, however, does not regulate the selection of employees or the evaluation of competency. All universities are regulated by the Universities Act (558/2009), according to which universities define the qualification requirements of staff and the procedures for recruitment in the university rules (Section 31). Professors can be recruited either through an open vacancy or by invitation. Invitation without public notice of vacancy is an exception and can be utilised only if the invited professor is an academically distinguished person who indisputably fulfils the qualification criteria or if the position is non-permanent (cf. Pietilä, 2017; Universities Act 33 \$). In addition to traditional vacancy-based recruitment (open vacancy), universities may 
decide on tenure track procedures. However, external evaluation of the candidates' qualifications is required by legislation in both cases, although the university has freedom in choosing the evaluators (Universities Act 33 $\$)$. Generally, decisions regarding the competency and selection procedures of employees fall within the scope of university autonomy, and the law grants the same autonomy in the recruitment processes for both universities under public law and foundation universities. However, the foundation universities were the first to adopt the tenure track process, introduced later to some of the universities under public law.

Labour law does not obligate universities to make administrative decisions on personnel selection, and thus they are not required to justify such decisions. However, a university must be prepared to demonstrate why the appointed person was regarded as the most qualified for the task. Universities are also obliged to demonstrate the non-discriminatory nature of recruitment under the Non-discrimination Act (1325/2014) and the Act on Equality between Women and Men (609/1986). An employer may not discriminate against applicants based on age, gender, or other similar personal characteristics. For example, the Finnish Ombudsman for Equality reminded UTA in 2011 that the university must always carry out a comparison of merits when there are both male and female applicants (13.6.2011 TAS432/2010, dnro 473/2009).

Whether selection for academic tenure is seen as falling under labour law or being an administrative decision, the university must factually compare the applicants' merits. The job description, confirmed in advance by the employer, plays a central role in this comparison. The comparison should be based on objectively demonstrable merits, and the merits under comparison should be apparent in the application documents (HE 19/2014 vp, p. 73-76). Typically, the following merits are compared in universities' selection procedures: research, teaching and societal services (Clark, 1987). According to Levander et al. (2019), administrative proficiencies are sometimes included in tenure track evaluation. Different merits can be given different weights, especially concerning the job description.

It should be noted that the purpose of regulations targeting universities is not to restrict the employer's right to choose the most suitable and best person for the position; rather, to ensure decisions are made on a 
non-discriminatory basis and on comparison of merits (Bruun $\&$ von Koskull, 2012). The subjects of discrimination and merit evaluation in recruitment are controversial; there is a certain level of resistance to addressing gender and equality issues outright in the recruitment process as recruitment has always been considered solely based on merits (van den Brink et al., 2010). In this view, merit is not problematised as an objective criterion. There are studies on the paradox of meritocracy and the difficulties of defining and quantifying merit as well as on discrimination in recruitment processes and merit evaluation (Castilla \& Benard, 2010; Nielsen, 2016; van den Brink et al., 2010). Despite claims that "in true meritocratic systems everyone has an equal chance to advance and obtain rewards based on their individual merits and efforts, regardless of their gender, race, class, or other non-merit factors," meritocratic organisational values have been shown to favour males over equally qualified females and other under-represented minorities (Castilla \& Benard, 2010 , p. 543). Recently there has been a tendency to measure, rationalise and access academic activities, despite the unquantifiable character of academic results and work such as publications or teaching (Musselin, 2007, p. 11).

\section{Recruitment and Tenure Track Systems in Finland}

The tenure track system originates from, and has been mostly adopted by, universities and colleges in the United States, where tenure was initially intended to promote academic freedom from external accountability in exchange for serving the greater public good (Finkin, 1996; Kezar \& Sam, 2011; Rhoades, 2010), but the tradition of academic freedom associated with tenure has cracked lately as, especially public universities, have decreased the number of tenure positions and increased other, more flexible contracts (Ehrenberg, 2012; Siekkinen, 2019). In Finland, however, the still recent tenure track is viewed as a privilege granted to those who undergo a peer review process to prove themselves as scholars, even though criticism has been leveraged by the Finnish Union of University Professors (Pietilä, 2015). 
In many European countries, tenure track implementation is related to internationalisation, competition, profiling and the evaluation of (research) performance. Two recent trends are particularly important in this context. First is the increasing competition among European universities to become top-level academic institutions. Second, because of this competition, universities are now trying to recruit the best scholars internationally, which has increasingly globalised the academic labour market (Mohrman et al., 2008; Pietilä, 2015; Regets, 2007; Välimaa et al., 2016), a trend that has also led to universities attempting to become more comparable to other academic institutions. When attracting international scholars, for instance, having a career progression model that is familiar across national borders is particularly important (Arnhold et al., 2018).

In Finland, the introduction of the tenure track system has been justified by competition by and comparability with other higher education systems (Kivistö et al., 2019). It has been implemented in Finnish universities in an attempt to increase attractiveness among international applicants. The system was introduced, coincidentally, alongside the new university law in 2010 and was first adopted by Aalto University, followed soon by others. However, so far, only Aalto uses tenure track as its dominant recruitment model (Kivistö et al., 2019), while other Finnish universities fill most positions through other recruitment methods. There are organisation-specific differences in tenure track recruitment, whose model has been developed over the last decade (Kivistö et al., 2019; Pietilä, 2017; Välimaa et al., 2016), the main difference being related to the entry and exit phase, as well as promotion (Arnhold et al., 2018). In the tenure track, the possibility of progressing to full professorship is defined with set targets and a schedule; in the open vacancy model, the only possibility to advance is to apply for another position in an open call. Positions in teaching and research outside the tenure track can be varied, from fixed-term researcher positions to teaching specific lecturers or full permanent professorships. This has led to a situation where many academics are stuck in a position without advancement opportunities. Accumulating merits might also be difficult in other positions, whereas in tenure track positions it is part of the job description. Many entry-level open vacancy positions are fixed term, and the evaluation of the candidates is based on requirements of the task and not potential, as in the 
tenure track. The more senior fixed-term vacancies are considered as positions from which the employee either retires or resigns. The major difference can be summarised in that tenure track positions include the aim of becoming more merited and advanced within the position, whereas in other tasks there is no such definition inherent to the position. Tenure recruitment should thus focus on the potential of the candidate, whereas open vacancy focus on the merits and the requirements defined in the call for the particular position. From a legal perspective, the differences are related to the question of how potential can be evaluated. The evaluation of set requirements can be more easily questioned or justified based on set criteria (See Kivistö et al., 2019; Siekkinen et al., 2016).

Both recruitment processes usually involve external evaluation, although there may be some exceptions in filling an open vacancy. The evaluation typically considers teaching, research and societal service which are differently emphasised and valued across universities and by different people within the university. Macfarlane (2005) argues that some academic responsibilities are emphasised, while others are neglected in the hiring and promotion criteria. Although external evaluators do not make the decisions, their evaluations may have a significant impact (Pekkola, 2014). Those making the recruitment decisions for academic positions in the university serve as institutional gatekeepers, and their role in emphasising the different evaluation criteria is crucial in the process (Levander et al., 2019; Merton, 1973). Different actors, such as academics, administrators and high-level management, exert different kinds of power in the process. Our interest is not in evaluating the actual qualifications of the applicants, rather in examining how they have been evaluated in the recruitment process to theoretically define what kind of power these instances represent.

\section{Collection and Analysis of Data}

To examine the processes, we obtained data on the tenure track recruitment 2011-2016 in specified fields. Due to the limited scope and focus on a particular field, we acquired only five case studies as examples of the 
recruitment process in the two universities at different times during the period.

We collected the following documents for each case analysed:

- Setting the open tenure (establishing the need)

- The recruitment call

- Evaluations of qualifications (including a trial lecture)

- External expert evaluations

- Memos of the working group evaluating teaching skills, research merits, and candidate suitability

- Summary of the applicant's evaluation

- The dean's proposals for the board, with justifications

- The board decision

We excluded the application documents and their annexes from our examination, as we did not aim to evaluate the candidates as such. Other proposals, materials, and decisions related to the process and the selection decision were also used to support the analysis. The material available for each tenure recruitment case was similar, but there were differences between the universities and in some cases; for example, applicant summaries were more detailed than in others.

The analysis was conducted by examining the documents using the chosen theoretical approach of the three different powers-bureaucratic, professional and managerial-and defining the instances of use of the different types of power.

As the data set consists of few cases, no broad conclusions can be drawn, but we believe the cases are representative of their organisations at the given time. We looked at three cases from TUT, 2011-2016; these represent a change in the TUT tenure process (as they are from different times for the same department). The development of the tenure process is also manifested in the institutional-level documents and instructions we used as background material. We examined two tenure track recruitment cases from UTA 2013-2015. These five cases represented all the tenure track recruitments in the specified fields since tenure track had been introduced in these universities. 


\section{Influence and Actors in Recruitment: Bureaucratic, Managerial and Professional Powers}

Following Pietilä (2017) and van den Brink et al. (2010), we approach tenure track recruitment as a "site of political struggle." We define the different powers that compete in the recruitment process as bureaucratic, managerial and professional. Their goals, and the people who exert them, differ.

Bureaucratic power (Weber, 1978) may be defined as the legal power related to rules and regulations. Administration follows the administrative tradition, primarily adhering to the process and definitions of the university and unit-level recruitment instructions. Being impartial and following regulations are the main virtues; the aim is to ensure that the process is fair, objective, transparent and follows the rules and legislation. Tenure track committees represent new controlling bodies through which universities influence their research fields and the recruitment of academics (Pietilä, 2015). The administrators and HRM experts typically act as gatekeepers, as applying the tenure track model is said to require strong HRM (Kivistö et al., 2019). Bureaucratic power cannot be ignored in any recruitment process as that could cause the recruitment to be illegal. By creating more detailed tenure instructions, universities have become stronger organisational actors, but, at the same time, these bureaucratic powers can "limit the freedom of departments to respond to field-specific needs" (Pietilä, 2015, p. 387).

Managerial power (Parsons, 1991) in higher education belongs to highlevel managers, such as deans and department heads. Managerialism, describing the ideology of management, spread to universities and other public sector organisations from business, emphasising competition, marketization of public sector services, monitoring performance and outcome measurements (Deem, 2004; Deem \& Brehony, 2005; Klikauer, 2015). As management turned into an 'ism', it had to have a proper ideology, one targeted at the future: "It has become common to see ideology as a set of ideas that constitute goals, expectations and actions"; it is a vision (Klikauer, 2015). Therefore, managerialism and managerial power 
in recruitment emphasise future potential. The managerial ethos (Kallio et al., 2016) is based on the basic assumption that managers should have freedom to manage because they are accountable for organisational performance (Vedung, 2010). The approach also emphasises the role of management in setting systems and metrics related to organisational goals and for allocating resources (Kallio et al., 2016).

The change towards more managerial practices in personnel policies in Finnish universities has occurred gradually with the introduction of practices related to performance-based management (Deem, 2004; Kallio et al., 2016). The first culmination point was a change of legislation on civil servants in 1992, when universities were granted the right to terminate, establish and alter the positions and vacancies of their own staff members. Further steps were taken until 2010, when universities were given the independent status of an employer (Kuoppala et al., 2015; Pekkola, 2014). New public management and managerial practices were introduced into higher education institutions, also with the assumption that a managerialist approach was more effective in carrying out strategies and organisational change, a view especially embraced by polytechnics and corporate higher education institutions where managerial practices were adopted more eagerly than in more traditional universities (Allen, 2003; Gibbons et al., 1994, p. 82; Santiago \& Carvalho, 2012).

Managerial power is primarily applied by university managers and is therefore associated with institutional or disciplinary strategies. Deans and department heads represent the organisational culture and are inclined to define and adhere to the profiling and strategic aims of the university. Deans are identified as key persons using power, particularly in the recruitment of more senior-level positions (Välimaa et al., 2016). However, Pietilä (2015) found that with hierarchical governance structures, deans and department heads faced tensions, especially if the tenure track procedures and instructions were not well defined.

The managerial approach has been contrasted with the traditional academic collegial practices at universities to the extent that some claim that more business-like and managerial approaches fragment higher education institutions and set academics against professional managers (Allen, 2003). If we consider managerial power to be more strategically focused and future oriented in the recruitment process, recruitment decisions 
would be based on the profiling of disciplines and fields according to the university's mission. Tenure track is said to entail a stronger role of university management and to be committed to the institutional mission (Kivistö et al., 2019, p. 121; Pietilä, 2015) and has been identified as a means to "introduce and strengthen strategic research fields" (Kivistö et al., 2019, p. 133). (See also Arnhold et al., 2018; Välimaa et al., 2016.) Often, this strategic defining of the position is made before opening the call, but it also occurs when justifying the choice of a particular candidate. It should be noted that academic excellence is entwined in this discussion, so the profiling areas of the institution are those where there is (an expectation of) world-class research.

The third power is professional power (Goode, 1957; Weber, 1919), utilised by professors and academics and which in the recruitment process is anticipated to focus primarily on academic excellence and evaluating (past) academic merits. The prevalent assumption is that decisions should be made by academics. This view permeates the attitudes and behaviour of many of the senior academics who also might resist the strategic organisational approach through managerial power, partially because it is perceived as an attack on their professional identity and power (Allen, 2003, p. 85). The open vacancy model is said to promote a "stronger role of the academic profession in recruitment" (Kivistö et al., 2019, p. 121). In the recruitment process, professors represent the disciplinary tradition, and they also largely define what the discipline is about when they act in the tenure group. The disciplinary definition of power is often located outside of the organisation in an international community of scholars. These senior academics of a particular discipline also act as gatekeepers for the discipline. Similarly, the external academic peer review evaluation is one form of professional power. Although it empowers academics, it is also used by university managers (Musselin, 2013).

The picture below (Fig. 16.1) illustrates how these three powers can occur simultaneously in the recruitment process but still conflict in practice. Bureaucratic power emphasises the rules and regulations of the recruitment process and supports the merit-based evaluations of the candidates. Managerial power is applied by the university managers, who emphasise the strategic goals of the organisation in the recruitment processes and thus pay more attention to the potential of the candidate; 


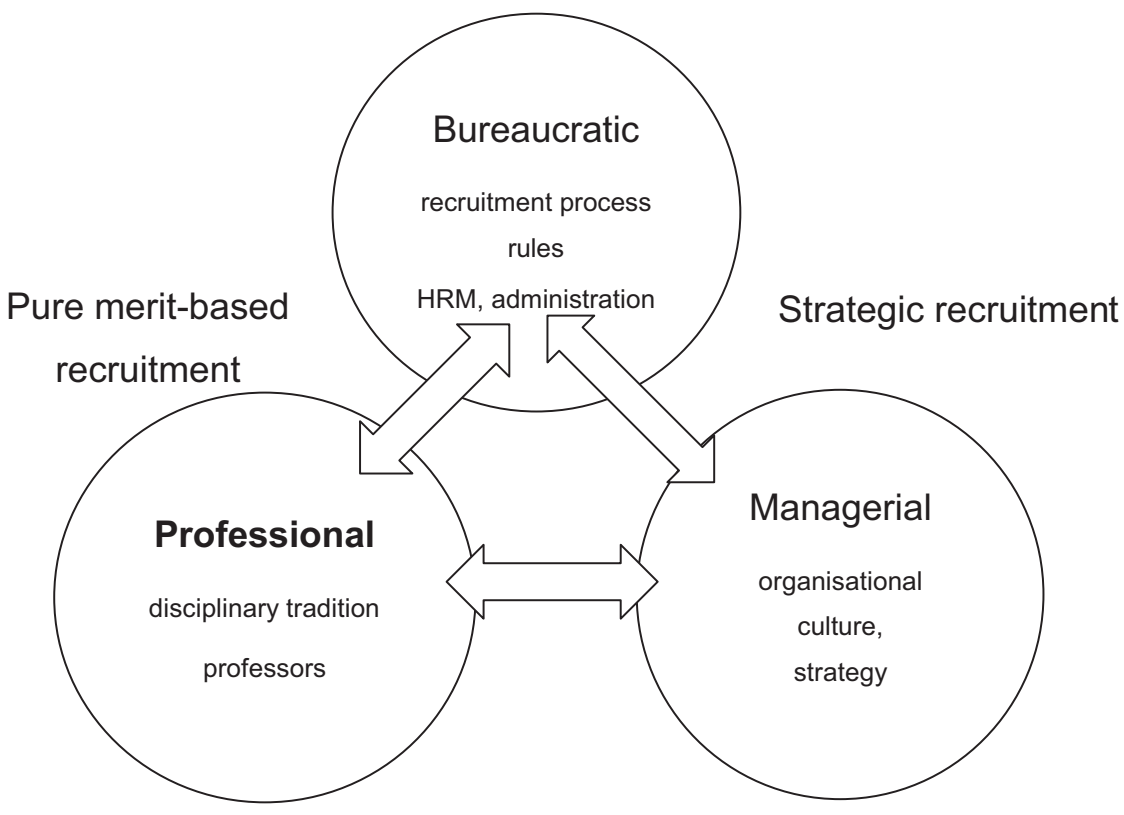

Profiling disciplinary

recruitment

Fig. 16.1 Different powers and persons utilising power in university recruitment

recruitment is strategic and aims to find future talent. Professional power counts on scientific evaluation based on the disciplinary tradition made by professors; recruitment is directed towards disciplines aiming to secure continuity in the faculty.

These powers have implications for recruitment. A combination of bureaucratic and managerial power can be associated with strategic HRM, in which the academic managers and HR professionals play an important role in recruitment. In theory, with the combination of bureaucratic and professional power, recruitment can support the academic oligarchy. Merit is defined by professionals and verified by the bureaucratic process (Clark, 1983). Further, this combination of managerial and professional recruitment could lead to merit-based recruiting that supports the disciplinary profiling planned by academic managers. 
However, it should be borne in mind that the different powers may have different interests and compete rather than complement each other. Merit-based recruitment supports the selection of senior academics with accumulated merits, talent recruitment supports the selection of "hungry" academics with verified potential (e.g. external funding, networks and top publications) and profiling recruitment supports the selection of candidates within the right field of study.

\section{The Recruitment Process in Tenure Track}

In TUT and UTA, different recruitment processes have generally been used, with positions filled through both open vacancy and tenure track recruitment. Our main focus is on the tenure track process at TUT with comparisons on the tenure track used at UTA. In the following, we will look at the process at TUT and UTA, starting with the opening of the position to the justification of the selected applicant.

\section{Defining the Position}

The tenure track process starts with defining the need for recruitment and defining the specific (sub) discipline in which the recruitment is targeted. The definition of the academic discipline comes from the unit level (the department, in our cases), but it must be confirmed at the institutional level. At this stage, this is already a strategic allocation of resources and a possibility for negotiating the needs between the department and the organisation. These aims may be parallel, but there may also be conflicting interests as the opening of the position is "a political endeavour, involving negotiations between multiple actors" (van den Brink et al., 2010, p. 1463). Collegial tripartite bodies have lost their importance in the recruitment processes. Who has the power to define the open position depends on the level of the position. Postdoctoral researcher and university lecturer positions are mainly defined by the head of the department, whereas the working group has an important role in higher-level open vacancies and tenure track recruitments (Välimaa et al., 2016). In 
any case, the definition of the open position is a negotiation between different level managers (e.g. department heads and the dean) and within the working group. Pietilä (2015) found that, with hierarchical governance structures, deans and department heads face tensions, especially if the tenure track procedures and instructions were not well defined. Tenure track committees represent new controlling bodies by which universities influence their research fields and the recruitment of academics. By creating the tenure instructions, universities become stronger organisational actors, but at "the same time they limit the freedom of departments to respond to field-specific needs" (Pietilä, 2015, p. 387). The recruitment process rules need to be followed, and thus each open position needs to be justified. The powers utilised at this point can be studied by looking at the justification of opening a (new) position, whether it is filling a position that has been left vacant due to retirement or job change (as usual with vacancies) or a new tenure position based on institutional profiling. When the position is opened for tenure track, the tenure level is not strictly defined but set on a broader scale as it can be targeted at assistant, associate or full-professors or all levels at the same time. The level of recruitment can be defined more exactly according to the qualifications of the applicants. The level of the tenure recruitment may also vary depending on the reasons why the position has been opened. When tenure track was recently adopted at TUT, there was also tenure recruitment at more senior levels (full professor). A more senior applicant might be desired due to retirement. In this case, the tenure track recruitment can resemble an open vacancy. Recruiting tenure track at the assistant professor level would seem to be a more strategic approach for a longterm staff development plan.

For tenure track recruitment, a tenure working group is set up to conduct the recruitment process, a practice similar in most open vacancy recruitment at similar levels. At TUT the tenure working group included internal representatives, such as department heads, professors from the field, HR experts, external academics and also industry representatives. The industry representative was a peculiarity of the technical university, not used at UTA. 


\section{Advertisement and Application}

The field of the open position and the applicant criteria should be clearly stated in both the open vacancy and the tenure recruitment call. The criteria are important as they are used for evaluating the applicants, and the recruitment decision needs to be justified. After the decision is made to open a tenure track position, the bureaucratic power of the administration and HRM takes on the process. The opening of the position, advertising the call, receiving applications and so on are part of normal recruitment and $\mathrm{HR}$ processes, regulated and managed similarly in most organisations.

\section{Evaluation}

After the applications have been received, the primary evaluation and shortlisting of the candidates is first done by the tenure working group to define which candidates are evaluated by the external experts. The external academic evaluation is a common practice in the tenure track, although there might be exceptions when only the working group makes the evaluation.

We looked at the recruitment criteria, how they were evaluated and whether there were differences in the importance placed between the criteria, evaluation and emphasis in the working group or the external evaluation. Generally, the criteria were related to the three tasks of universities: research, teaching and outreach activities. When comparing merit, documented attainments are considered most important, but in tenure track, especially, potential compatibility with the working environment and particular substance skills is also emphasised (Välimaa et al., 2016, p. 46). From a meritocratic perspective, we expect the academic task, research and publications to be the most important. These are also criteria that both the working group professors and the external experts are likely to emphasise.

We can also ask what parts of the evaluation are considered to be an assessment of qualifications (merits, which are public) or of the person 
(personality and character, which are confidential). The application documents are similarly public in both types of universities, and there is no difference in whether the application documents are seen as employmentor administrative-related preparatory documents. Only the observations of an individual's personal characteristics, such as psychological assessments, are confidential (Section 24 of the Act on the Openness of Government Activities). However, the actual practices of transparency and accountability of these processes in organisations vary; generally, universities have been somewhat reluctant to disclose detailed information on the actual recruitment process. It is also noteworthy that, if the assessment is not open or criteria are obscure, it increases the risk of bias in all the evaluation phases (van den Brink et al., 2010, p. 1459). Even if the assessment criteria are stated, some of them can be disputable, such as potential. Similarly, criteria may vary according to the different tenure levels the candidates are evaluated for. As the editors note in their introduction of this volume (Forsberg et al. 2021), a variety of biases may affect peer review including

epistemic bias; values and beliefs (O'Meara et al. 2016); gender bias and stereotypical judgement (van den Brink et al., 2010) and reputation of alma mater, habitus and networks, to mention a few.

\section{Decision and Justification}

As noted earlier, the criteria set in the tenure call are important because they not only guide candidate evaluation but also should be used to justify the selection. We also attempt to determine whether the decisions were justified concerning the criteria set in the tenure call or in relation to other aspects. In addition, it is necessary to justify the decision from a legal perspective, particularly if in cases of suspicion of discrimination. The possibility of bias in recruitment and evaluation is nowadays better recognised, and gender aspects have been included in recruitment protocols (van den Brink et al., 2010).

In the following, we will analyse the tenure track cases, focusing on the cases of the technical university in particular, and examine the UTA cases in order to compare them to the TUT case. 


\section{TUT Findings}

According to the TUT tenure instructions, "the aim is to attract and to keep competent, creative and inspiring research and teaching staff at TUT and in that way enforce the status of TUT as a high-level and international research university...." This emphasises managerial power, where the strategy, position and ranking of the university are seen as an integral aim of the tenure process. It may be said that this reflects the introduction of new public management, which has brought corporate culture aspects like managerialism into higher education. According to the documents on setting up the tenure system at TUT, there is a focus on evaluating the potential of the candidates and the main criteria should be the potential of the candidate to advance on the tenure track to more demanding positions. This statement also reinforces managerial power as the temporal target is in the future and potential is emphasised. The definition of tenure already establishes a certain power balance, but, in the following, we will look at how the powers are manifested in the actual process of three different tenure processes at TUT-one in 2012 and two in 2016. In the 2012 and the 2016 calls, external evaluation was used, while the 2016 instance was carried out by the tenure working group only, which left room for managerial power, represented by the dean and the department head, in the process.

\section{Tenure Call}

In the TUT instructions, the disciplinary boundaries are not enforced rigidly; this is to allow for many applicants. This might further weaken the professional power of academics (professors), who are prone to guard disciplinary boundaries and define tenure calls in a particular (sub) field. This is perhaps added to the tenure track instructions because the degree of specialisation in engineering is generally high. In the TUT cases, computer science also seems closely connected to another discipline: signal processing. The division between these fields is shifting, and the 2012 tenure track was transferred to the Department of Signal Processing based 
on the suggestion of the Department of Computer Science. Based on some of the materials during this process, the definition of the field narrowed the potential applicant pool from the perspective of computer science but broadened it towards signal processing. The desire for a broader field might be contradictory, its aim to strategically define the recruitment concerning the department and university profile. In this TUT case, one candidate withdrew their application because the position became so closely defined to signal processing that it did not fit their profile. Even if the field of the open positions need to be defined so that they attract enough applicants, defining the subfield in more detail may be justified by the department's profiling.

\section{Setting up the Working Group}

The tenure working group that prepares the tenure track position opening usually has one or two external experts, who may be academics or, in TUT, also industry representatives. In the TUT examples, there was one external academic and one industry representative in the 2016 case, where the evaluation of the candidates was performed by the working group only. There were no external experts in the tenure group in the 2012 case. In the other 2016 case, the external academic representative for the TUT group was chosen by UTA, maybe anticipating the approaching merger or as a reflection of the thematic closeness of the fields in the two institutions. Industry representatives should be high-level experts in the fields but are not required to hold a PhD. In the 2016 TUT cases, there was an industry representative who had a doctoral degree and an expert who did not. Although experts with doctoral degrees may be seen as knowledgeable of academic criteria, industry representatives are not that likely to align with the professional power of academics. They are nominated to the working group to bring a different viewpoint, that of the industry stakeholders. Their role and views seem to be more important in a technical university in industry-related fields than in other kinds of disciplines. The close relationship with industry stakeholders is a particular identity feature of the technical university as an organisation (Vellamo et al., 2019). 


\section{Evaluation}

According to TUT's instructions, the evaluation should be open and equal, and the evaluators should have the highest possible expertise. Let us assume this refers to both the internal evaluation done by the tenure working group as well as the external evaluation. In addition, fairness and transparency may also be seen as traits of bureaucratic power and the legality of the process. These traits are important in the justification of the evaluation: if the evaluation is fair and transparent, it is possible to examine how and on which explicitly stated grounds the evaluation is based.

External scientific evaluation is used in the tenure track for the shortlisted candidates chosen by the tenure working group. External evaluation can be seen as a form of peer review despite the differences in the recruitment models. Peer review has been the primary institution of modern science evaluation, and its use has extended to more evaluation practices. According to Musselin (2013), scientific evaluation empowers academics since university managers are dependent on it in many university processes. The external evaluation peer review process is moderated by the definition of criteria and qualifications set in the call for application and, more generally, by the recruitment process descriptions. The external academic evaluators are selected for their expertise in the field of the open position, but, since they are nominated by the recruitment group, there may internal power struggles in this process.

External evaluators are experts representing the professional power of the international scientific community. When the tenure track system was introduced at TUT, gender and other diversity factors were almost completely missing from the tenure process description (TUT tenure process Academic Board decision 22.11.2010). In TUT, the Human Resources Strategy for Researchers (European Commission. (n.d.). Human resources strategy for researchers HRS4R) evaluations of 2012-2014 paid attention to the gender imbalance of the external experts and a recommendation was given to include more female evaluators and also to pay attention to the gender balance in the tenure working group. In our case from 2016, there was also a female evaluator, an effort to 
ensure diversity in the evaluation in practice perhaps. It is noteworthy that the legislation does not directly require the representation of both genders in the evaluators but refers to more generally taking into account gender equality in all decision-making. Additionally, because of the merger process and new joint tenure model, TUT's tenure actions on gender balance and addressing gaps in employment due to family leave were postponed. In the TUT case examples, there were few female applicants; in one (2016), a female applicant was sent for external evaluation but was not selected.

Although there are set criteria for the external evaluation, there is still considerable room for interpretation of the criteria and evaluating the merits of each candidate. Moreover, the weight placed on each aspect may differ according to the evaluator, and the recruitment committee may steer the selection decision in a different direction than the external evaluators. In TUT, the tenure working group seemed to place different weighting on the evaluation criteria depending on the tenure level. Emphasis on a certain criterion was justified by the profiled need of the department (2016), the complementarity of expertise within the unit's faculty (2016) or if it was mentioned in the tenure call (2012).

According to the TUT tenure track criteria, research papers are evaluated for the number and level of journal publications, and the candidates' citations and $\mathrm{H}$-index are listed. In both TUT 2016 recruitments, there were also Excel sheets summarising applicants' quantitative data. However, based on these cases, it is hard to tell how much weight this had in the recruitment. Some evaluators seemed to emphasise these aspects in their evaluations to justify the academic research excellence (or lack of it) of the candidate. In the 2016 case, where the external evaluators had noted the number of high-level publications as a weakness of the candidate, the tenure group justified the number as "a consequence of a long period of work in industry."

In TUT, experience as a project leader and attained research funding are seen as important factors for the highest tenure positions. This is also mentioned in the evaluation of the candidates, but somewhat surprisingly also at the assistant professor level (2016 case). 
Related to both teaching and education, the supervision of master's and doctoral theses is seen as an important merit for those applying for higher tenure or full professor positions. However, there may be different institutional policies regarding who is allowed to supervise doctoral theses, and, in one of the 2016 external evaluation statements, the candidate's lack of supervision experience was reportedly due to the policy of the university in which the candidate was currently employed.

Industrial experience seems to be important to TUT. In the 2016 external evaluation case, a candidate who had a good academic track record but had spent an entire career in academia was evaluated as weak in terms of industrial experience. The candidate selected by the tenure group had strong industry experience, a moderate academic track record and a "not very thorough teaching record" (TUT 2016 tenure track external evaluator statement) Apparently, a lack in one category could be compensated by achievements in another. Industry experience seemed to be more important than academic merit and teaching skills for the tenure working group in this case. This may be a particular feature related to the discipline and the technical universities, and more acceptable in the engineering field (Whitchurch, 2012, p. 6). However, this emphasis was also justified by the criteria set beforehand: industry experience was specifically mentioned in the tenure call even though the importance of the different criteria listed was not indicated in the call. Emphasising industrial experience is also contradictory to the trend observed in the national tenure track practices as, it is said, it is difficult to move to tenure track from outside of academia (Välimaa et al., 2016 p. 53).

The shortlisted candidates also underwent psychological tests, the results of which were utilised by the working group in their evaluation. While could be perceived as impartial external evaluation, it also support $[s]$ the perception of the working group on the candidates(). Even so, it seems unlikely that psychological evaluation would significantly affect the final recruitment decision. In some cases, it was mentioned as affirming the perceptions of the tenure group regarding the candidates. In the 2012 case, the psychological tests indicated that only the selected candidate was clearly suitable for the position. Psychological tests may be seen as supporting managerial power and enabling the selection of the most appropriate candidate. 


\section{Decision and Justification}

In one of the 2016 recruitment processes, although the external evaluators pointed out substantial weaknesses in each candidate's profile, the working group chose to value industry experience over research merit. This seems somewhat exceptional based on previous studies and might not be a typical case, even at TUT. The emphasis was justified by the department's strategy and a profiling factor that sets the department apart from all other Finnish software engineering centres. In the tenure call, industry had a less important role: "practical experience in industry software projects is seen as an advantage" (TUT Tenure call 2016). This could be interpreted so that industry experience would not be a core requirement but rather an additional asset. This is also a case where the recruitment criteria, such as industrial experience, exceeds traditional notions of academic merit and the tenure working group exercised its decision power over that of the external evaluators.

\section{UTA Findings}

In UTA, the School of Informational Sciences (SIS) operated until 2017, when it was split into two faculties, and Computer Science began operating within the Faculty of Natural Sciences. After the Tampere University merger in 2019, it was included in the Faculty of Information Technology and Communication Sciences (ITC). Both tenure track calls examined took place in SIS, specifically in the field of data analysis, in 2013 and 2015 as assistant professor (2013) and as assistant professor or postdoctoral researcher (2015). The use of a postdoctoral researcher as a tenure track title reflects the variations in the system nationally as even the terms were not uniform.

\section{Tenure Call}

In both recruitment calls, the requirements were specified clearly, and the tenure level(s) for the position was set in the call. The calls included the same requirements: "the person appointed associate professor must hold 
a doctoral degree, high-level academic qualifications and experience in directing scientific research, be able to provide high-quality, researchbased instruction as well as to have a track record of international scientific activities ... [and be] fluent in English." (UTA tenure calls 2013 and 2015)

In the recruitment calls, research and teaching were both mentioned. In the other call (2013), teaching was emphasised as playing a "central role in planning this master's degree programme and [the associate professor] will mainly teach courses" (UTA tenure call 2013). In the other call (2015), the focus was on research, and the recruitment targeted one of the strategic focus areas of SIS, emphasising managerial power and the department's strategy. The position where teaching was emphasised does not represent a typical tenure track position, which usually focuses on research, but seems more like an open vacancy type of position with emphasis on teaching. However, in the new UTA, there are plans to create a new teaching career track parallel to the tenure track.

\section{Evaluation}

SIS had evaluation guidelines for tenure track recruitment, addressing that evaluations were being made in three areas: (1) research, (2) teaching and (3) activity in the scientific community and academic leadership. How these dimensions were emphasised in each recruitment depended on the case. In their research evaluation, publications in JUFO (Finnish Publication Forum ranking of scientific journals)-recognised journals were valued. In teaching evaluation, producing materials for teaching, pedagogical training, awards and teaching evaluations were valued. In general, those kinds of activities and merits are recognised in evaluation required at the next level of the tenure track, but teaching seems to have more relevance than in the TUT tenure track cases.

The assessment was based on openness, reason and eligibility in an international comparison. The associate professor should have published high-quality scientific research articles, designed curricula and planned study modules. Moreover, the candidate should have had teaching experience, a recognisable personal research field, an acknowledged position 
in the research field and have supervised several theses. In addition, if they had received (or pursued) external funding, and had started their own research group, these were considered positively. The list was extensive and similar to the expectations at TUT, except for industry or other work experience, which are not mentioned at UTA. Supervising theses was considered an important aspect for both universities.

In the first recruitment case (2013), the tenure working group shortlisted as many as 6 of the 20 applicants (including one woman) for external evaluation. The evaluators completed the first round of evaluation and selected three candidates for interview. Two of the three external evaluators selected the same top three candidates with similar justifications, emphasising research productivity and quality, engagement with the research community, solid research plans, involvement in research projects and having received funding, but they also placed great value on $\mathrm{PhD}$ supervisory experience. One of the evaluators placed more emphasis on publications than the others did, and clearly reviewed the qualifications of the candidates more generally. In addition, this evaluator's top two was different from that of the other evaluators. Thus, it seemed that, using the same criteria, the external evaluators ranked the applicants differently. It is also noteworthy that teaching was not highlighted in the external evaluation.

One evaluator (with a more general view) gave some suggestions regarding what to ask the candidates in the forthcoming interviews. The evaluator also pointed out the challenges of the evaluation, such as different publishing cultures in this interdisciplinary field. Another (also with a more general view) listed all the evaluation criteria taken into consideration, saying that all six candidates submitted interesting applications, so "the university will have to decide what is most important and how the candidates would fit in with the rest of the school." This accentuates the university's autonomy, which it legally has in the selection process.

In the second recruitment (2015), the tenure track position was opened at two levels: university researcher and associate professor. Commonly, a university researcher is not included in the tenure track, showing an example of the non-standardised tenure track processes (but standardised later). There were 23 applicants for the position: 17 applied for the position of associate professor, the rest for the position of 
university researcher. The tenure working group, including the faculty manager, a student, a lecturer, two professors and the HR expert, presented two candidates for the external evaluators. The minutes of the faculty board meeting clarified that this internal group could choose the applicants to send to the external evaluators. This group also selected the external evaluators.

The first external evaluator emphasised research, teaching, activity in the scientific community and academic leadership. Although academic leadership was not mentioned in the call, these mostly aligned with the recruitment call. The other external evaluator stated that one applicant would be successful in the US, whereas the other would not. He stressed the publications (H-index and citations), research and conferences in which they had participated but also examined the applications, especially future research plans. The second evaluator mentioned he was not able to evaluate the teaching since he lacked material (e.g. quotes from students). Despite the differences in evaluation, both external evaluators proposed the same applicant for the position. The assessments were in line with the recruitment call, where the emphasis was more on research than teaching.

\section{Decision and Justification}

In the 2013 recruitment process, the applicants ranked as the top three by two of the external evaluators were interviewed. The tenure working group justified its selected candidate by indicating that they had "strong potential based on scientific and teaching merits to proceed in tenure track and become a professor." However, the candidate withdrew their application, so the faculty manager asked the rector to choose the second candidate on the list. This justification was related to teaching experience, active research activity and an innovative vision regarding a new master's degree programme. The candidate was said to have "promising preconditions." It seems that the first candidate had stronger research merit, whereas the teaching experience of the second one seemed stronger, and both criteria were sufficient to justify the selection. 
In the 2015 recruitment, the working group made its decision based on the proposals of the external evaluators. These evaluators agreed on the strongest applicant, both emphasising research merits, international collaboration and the preparation of funding proposals, as well as the applicant being graded as "good" at teaching.

It seems that in both these UTA recruitment processes, the power of the tenure working group was strong, especially in the pre-screening of candidates. Additionally, the actual recruitment call directed the recruitment from the beginning. The power of the department head and the working group was strong (Siekkinen et al., 2016). In the 2013 recruitment, the working group sent six applications to the external evaluators but in 2015 , only two. In the latter recruitment, the power of the faculty is manifested. They also chose the external evaluators, whose evaluations were in line with the recruitment calls, and the working group followed their views. Teaching was emphasised more in the 2013 recruitment than in 2015, which showed in the evaluations. In both cases, the rector agreed with the working group's proposal.

\section{Conclusions}

In this article, we were interested in how bureaucratic, managerial and professional powers were manifested in tenure track recruitment process, especially in the technical university. We examined the differences in the tenure track recruitment process in two universities to find out whether the powers were different according to the organisational form and organisational identity of the technical university.

Labour law regulations do not differentiate between public law universities and foundation universities. Yet, despite the legal aspect of publicity, the processes are not that open and transparent in either university. They seemingly have great autonomy in defining their recruitment processes and do not necessarily always follow their own internal regulations in the process.

We discovered that bureaucratic power was present in both universities' tenure recruitment processes. This could be seen as fulfilling the legal minimum, illustrated, for example, in the impartiality of the external 
experts required by law. However, the impartiality is only related to the personal relationship of the evaluators with the applicants and does not consider disciplinary or scientific partiality.

Even though tenure track evaluations are based on the three tasks of the university_-research, teaching and societal impact—different people evaluate these aspects in different ways, with varying importance placed on different criteria. The two universities seemingly place different priorities on the criteria. Based on previous research you might anticipate that research performance and success in acquiring research funding would be the most valued criteria for tenure track, but we discovered other priorities. While we only looked at a few case examples, some differences emerged in the recruitment processes between the two universities. Our case study showed that, although research is important, in the examined cases industry experience (TUT) and teaching (UTA) were also significant.

When opening the tenure call, the (managerial) power of universityand department-level strategy, often represented by the department head, is emphasised, whereas the tenure working group has significant power in shortlisting the candidates and naming the external evaluators. Often, department heads also have a position in the tenure group. In the TUT model and cases, managerial power seemed to play a strong part in all these phases of opening and defining the tenure, and the same strategyderived aspects were used in the selection justification. There was even one case where the tenure working group carried out the whole process, and managerial power almost completely excluded (the external) professional academic views from the process, even though the tenure group included two professors from the specific field (one from TUT and one from another Finnish university). The dean and department heads are academics themselves, but not necessarily from the discipline of the tenure position, and they also are considered to implement strategy. Why one of the TUT evaluations was carried out only by the tenure working group was not justified in the process, except by a reference that the evaluation was carried out according to the TUT tenure track instruction. The tenure group in TUT used its power, in one case, by carrying out the evaluation itself and, in another case, by deciding against the evaluations 
of the external experts, whereas in the UTA cases, the external evaluation group's evaluations were followed.

The cases demonstrate that the decision of the tenure working group can differ from external expert views. In such cases, managerial power was used to justify the decision, with the department's strategic profile mentioned as the main reason for not following the evaluator's recommendations. Bureaucratic power, focusing on fairness and transparency, might have been compromised, and thus one might question whether institutional tenure criteria emphasising research and academic achievement were followed.

Based on our findings, the powers interact and overlap with each other in a tense relationship. Bureaucratic power defines the minimum requirements for the process that must be ensured to make the process legitimate. Within this legal frame, managerial power defines the limits of the use of professional power. Professional power appears to have the most limited power in the process, yet it is still the central power enabling tenure recruitment since it defines merit and evaluates potential. Managerial power can influence the way these professional evaluations are weighted in the final decision and justification, and bring organisational strategy to the decision. All the recruitment is the result of a managerial decision in the sense that the management team has to accept the opening of the tenure and the board makes the final decision based on the tenure group's proposal.

It is possible that managerial power is related to the organisational form of the foundation university but even more so, to the identity of the technical university, which emphasises industry relations. The identity of the technical university is more strategically oriented and manifested in its tenure recruitment. The use of managerial power is revealed in the tenure process documents, but it would require further study and other data (e.g. interviews) to determine whether other powers are more strongly present in the non-documented aspects of the process or whether the managerial powers are also dominant. 


\section{References}

Act on Equality between Women and Men, 609. (1986). https://www.finlex.fi/ en/laki/kaannokset/1986/en19860609_20160915.pdf

Act on the Openness of Government Activities, 621. (1999). https://www.finlex.fi/en/laki/kaannokset/1999/en19990621_20150907.pdf

Allen, D. (2003). Organisational climate and strategic change in higher education: Organisational insecurity. Higher Education, 46, 61-92. https://doi. org/10.1023/A:1024445024385

Arnhold, N., Pekkola, E., Püttmann, V., \& Sursock, A. (2018). Focus on performance-World Bank support to higher education in Latvia (Vol. 3): Academic careers (English). World Bank Group.

Bruun, N., \& von Koskull, A. (2012). Työoikeuden perusteet. (2nd ed.) (Juridica; No. 4). Talentum.

Castilla, E. J., \& Benard, S. (2010). The paradox of meritocracy in organizations. Administrative Science Quarterly, 55, 543-576.

Clark, B. (1983). The higher education system: Academic organization in crossnational perspective. University of California Press.

Clark, B. R. (1987). The academic profession: National, disciplinary, and institutional settings. University of California Press.

Deem, R. (2004). The knowledge worker, the manager-academic and the contemporary UK university: New and old forms of public management? Financial Accountability \& Management, 20(2), 107-128.

Deem, R., \& Brehony, K. J. (2005). Management as ideology: the case of 'new managerialism' in higher education. Oxford Review of Education, 31(2), 217-235. https://doi.org/10.1080/03054980500117827

Ehrenberg, R. G. (2012). American higher education in transition. Journal of Economic Perspectives, 26(1), 193-216.

European Commission. (n.d.). Human resources strategy for researchers (HRS4R). Retrieved from https://euraxess.ec.europa.eu/jobs/hrs4r

Finkin, M. W. (1996). The case for tenure. Cornell University Press.

Finnish Ombudsman for Equality. (2009). 13.6.2011 TAS432/2010, dnro 473/2009. Statement of the Finnish Ombudsman for equality. https://www. tasa-arvo.fi/documents/10181/34936/Tampereen+yliopisto_432-10_johtajavalinnat.2.pdf/680a4266-1a21-4c57-aeb1-0900855787c7

Forsberg, E., Geschwind, L., Levander, S., \& Wermke, W. (2021). Peer Review in Academia. In Forsberg, E., Geschwind L., Levander, S., \& Wermke, W. (Eds), Peer Review in an Era of Evaluation. Understanding the Practice of Gatekeeping in Academia. Anthology Springer Nature. 
Gibbons, M., Limoges, C., Nowotny, H., Schwarzman, S., Scott, P., \& Trow, M. (1994). The New Production of Knowledge: The Dynamics of Science and Research in Contemporary Societies. London: Sage Publications.

Goode, W. (1957). Community within a community: The professions. American Sociological Review, 22(2), 194-200.

Kallio, K.-M., Kallio, T. J., Tienari, J., \& Hyvönen, T. (2016). Ethos at stake: Performance management and academic work in universities. Human Relations, 69(3), 685-709.

Kezar, A., \& Sam, C. (2011). Understanding non-tenure track faculty: New assumptions and theories for conceptualizing behavior. American Behavioral Scientist, 55(11), 1419-1442.

Kivistö, J., Pekkola, E., \& Pausits, A. (2019). Academic Careers and Promotions in Finland and Austria: System and Institutional Perspectives. In Mahat, M., \& Tabate, J. (Eds.), Achieving Academic Promotion. London: Emerald Publishing.

Klikauer, T. (2015). What Is Managerialism? Critical Sociology, 41(7-8), 1103-1119. https://doi.org/10.1177/0896920513501351

Kuoppala, K., Pekkola, E., \& Ranta, M. (2015). Tilivirastosta yksityiseksi yliopistoiksi: Työnantaja aseman muutos ja uudet palvelussuhteet. In K. Kuoppala, E. Pekkola, J. Kivistö, T. Siekkinen, \& S. Hölttä (Eds.), Tietoyhteiskunnan työläinen-Suomalaisen akateemisen projektitutkijan työ ja toimintaympäristö. Tampere University Press.

Levander, S., Forsberg, E., \& Elmgren, M. (2019). The meaning-making of educational proficiency in academic hiring: A blind spot in the black box. Teaching in Higher Education, 1(19), 1-19.

Macfarlane, B. (2005, October). The disengaged academic: The retreat from citizenship. Higher Education Quarterly, 59(4), 296-312.

Merton, R. K. (1973). The normative structure of science. In R. Merton (Ed.), The sociology of science: Theoretical and empirical investigations (pp. 267-278). University of Chicago Press.

Mohrman, K., Ma, W., \& Baker, D. (2008). The research university in transition: The emerging global model. Higher Education Policy, 21, 5-27.

Musselin, C. (2007). Are universities specific organisations? In G. Krücken, A. Kosmützky, \& M. Torka (Eds.), Towards a multiversity? Universities between global trends and national traditions (pp. 63-86). Transcript.

Musselin, C. (2013, June). How peer review empowers the academic profession and university managers: Changes in relationships between the state, universities and the professoriate. Research Policy, 42(5), 1165-1173.

Nielsen, M. W. (2016). Limits to meritocracy? Gender in academic recruitment and promotion processes. Science and Public Policy, 43(3), 386-399. 
Non-discrimination Act, 1325. (2014). https://www.finlex.fi/en/laki/kaannokset/2014/en20141325.pdf

O'Meara, K., Bennett, J. C., \& Neihaus, E. (2016). Left unsaid: The role of work expectations and psychological contracts in faculty careers and departure. The Review of Higher Education, 39(2), 269-297.

Parsons, T. (1991). The social system. Routledge.

Pekkola, E. (2011). Kollegiaalinen ja manageriaalinen johtaminen suomalaisissa yliopistoissa. Hallinnon tutkimus, 1, 37-55.

Pekkola, E. (2014). Korkeakoulujen professio Suomessa_kehityskulkuja, käsitteitä ja ajankuvia (Doctoral dissertation). Retrieved from Tampere University Trepo (2014-11-24T08:54:04Z). http://urn.fi/URN:ISBN:978-951-44-9654-7

Pietilä, M. (2015). Tenure track career system as a strategic instrument for academic leaders. European Journal of Higher Education, 5(4), 371-387.

Pietilä, M. (2017). Incentivising academics: Experiences and expectations of the tenure track in Finland. Studies in Higher Education., 44(6), 932-945.

Regets, M. C. (2007). Research issues in the international migration of highly skilled workers: A perspective with data from the United States (Working Paper No. SRS 07-203).

Rhoades, G. (2010). Envisaging invisible workforces: Enhancing intellectual capital. In G. Gordon \& C. Whitchurch (Eds.), Academic and professional identities in higher education: The challenges of a diversifying workforce. Routledge.

Santiago, R., \& Carvalho, T. (2012). Managerialism rhetorics in Portuguese higher education. Minerva, 50, 511-532.

Siekkinen, T. (2019). The changing relationship between the academic profession and universities in Finnish higher education (Doctoral dissertation). Retrieved from Finnish Institute for Educational Research, University of Jyväskylä. http://urn.fi/URN:ISBN:978-951-39-7931-7

Siekkinen, T., Pekkola, E., \& Carvalho, T. (2016). Change and continuity in the academic profession: Finnish universities as living labs. Higher Education, 79(3), 533-551.

Universities Act, 558. (2009). https://www.finlex.fi/fi/laki/kaannokset/2009/ en20090558.pdf

Välimaa, J., Stenvall, J., Siekkinen, T., Pekkola, E., Kivistö, J., Kuoppala, K., ... Ursin, J. (2016). Neliportaisen tutkijanuramallin arviointihanke: Loppuraportti. Opetus- ja kulttuuriministeriön julkaisuja, 2016, 15.

van den Brink, M., Benschop, Y., \& Jansen, W. H. M. (2010, November). Transparency in academic recruitment: A problematic tool for gender equality? Organization Studies, 31. https://doi.org/10.1177/0170840610380812 
Vedung, E. (2010). Four waves of evaluation diffusion. Evaluation, 16(3), 263-277. https://doi.org/10.1177/1356389010372452

Vellamo, T., Siekkinen, T., \& Pekkola, E. (2019). Technical education in jeopardy?-Assessing the interdisciplinary faculty structure in a university merger. In M. P. Sørensen, L. Geschwind, J. Kekäle, \& R. Pinheiro (Eds.), The responsible university: Exploring the Nordic context and beyond (pp. 202-233). Palgrave Macmillan. https://doi.org/10.1007/978-3-030-25646-3_8

Weber, M. (1919). Science as a vocation Wissenschaft als Beruf, from Gesammlte Aufsaetze zur Wissenschaftslehre (Tubingen, 1922), 524-555. Originally delivered as a speech at Munich University, 1918. Published by Duncker \& Humblodt, Munich. http://www.wisdom.weizmann.ac.il/ oded/X/ WeberScienceVocation.pdf

Weber, M. (1978). Economy and society: An outline of interpretive sociology. University of California Press.

Whitchurch, C. (2012). Reconstructing identities in higher education: The rise of third space' professionals. Routledge.

Open Access This chapter is licensed under the terms of the Creative Commons Attribution 4.0 International License (http://creativecommons.org/licenses/ by/4.0/), which permits use, sharing, adaptation, distribution and reproduction in any medium or format, as long as you give appropriate credit to the original author(s) and the source, provide a link to the Creative Commons licence and indicate if changes were made.

The images or other third party material in this chapter are included in the chapter's Creative Commons licence, unless indicated otherwise in a credit line to the material. If material is not included in the chapter's Creative Commons licence and your intended use is not permitted by statutory regulation or exceeds the permitted use, you will need to obtain permission directly from the copyright holder.

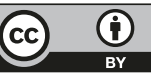

